$\mathrm{Oz}$

Volume 29

Article 8

$1-1-2007$

\title{
Temporal Temples
}

Eric Carlson

Follow this and additional works at: https://newprairiepress.org/oz

(c) (i) $\Theta \Theta$

This work is licensed under a Creative Commons Attribution-Noncommercial-No Derivative Works 4.0 License.

\section{Recommended Citation}

Carlson, Eric (2007) "Temporal Temples," Oz: Vol. 29. https://doi.org/10.4148/2378-5853.1448

This Article is brought to you for free and open access by New Prairie Press. It has been accepted for inclusion in Oz by an authorized administrator of New Prairie Press. For more information, please contact cads@k-state.edu. 


\section{Temporal Temples}

Eric Carlson

\section{“Less Is More, But Is Timeless More... or Less?"}

The concept of an eternal Architecture became institutionalized in the $1800 \mathrm{~s}$ with the notion of "le chef d'oeuvre" or "the masterpiece," which to this day still encumbers architects who strive to create works that remain unchanged and timeless. An illustration of an alternative attitude concerning this endless horizon of time became apparent while designing a museum for a 150-year-old Swiss watch company. The exhibit was to catalogue incrementally the capability of the timepiece to accurately measure and divide time into days, hours, minutes, seconds, $1 / 10$ th and up to $1 / 100,000$ th of a second in a relentless obsession to examine time inwardly. Our work follows this inward approach to exploring time, not by asking ourselves how the design of any one project can be timeless or petrified, but rather by analyzing and responding to the moment in the shortest possible intervals to create adulterated buildings in an endless pursuit of now.

To elaborate on the complex relationship temporality has to the Architecture of "now," I will present a number of projects we have built in recent times and discuss their unique rapport with regards to: changing speeds based on commercial forces, the change in perception of one project versus the organism of multiple simultaneous projects; and change as a program matic prerequisite of fashion. But first, to give time a scale in this recent the brief history of luxury retail architecture.

Only in the last ten years have individual luxury retail brands found use, beyond decoration, for architecture and architects. The impetus to create buildings, to shape multi-level spaces and to design facades was born from the demands of marketplaces to simply make stores bigger. From these pragmatic beginnings grew the idea of architecture as a direct urban branding opportunity and, residually, as communications topic within the mainstream press. Retail brands began hiring architects and in many cases "branded architects" to produce their temporal temples, frequently for the shopping frontiers of Japan where the customers are more savvy. The notable examples began with Louis Vuitton and followed soon after with Prada by OMA and Herzog \& de Meuron, Hermes by Renzo Piano, Dior by Kazuyo Sejima, and Tod's by Toyo Ito. A new typological variant on commercial building design was formally ordained and with that came shifts in the paradigm.

\section{Fast and Furious}

Within that short period our office has designed ten significant building projects and guided a handful of other architects through their designs for an additional ten projects. Each building, including interiors, on average was conceived and constructed in twelve to eighteen months. This high speed process is a particularly remarkable feat when considering the demands for innovative design from facades to

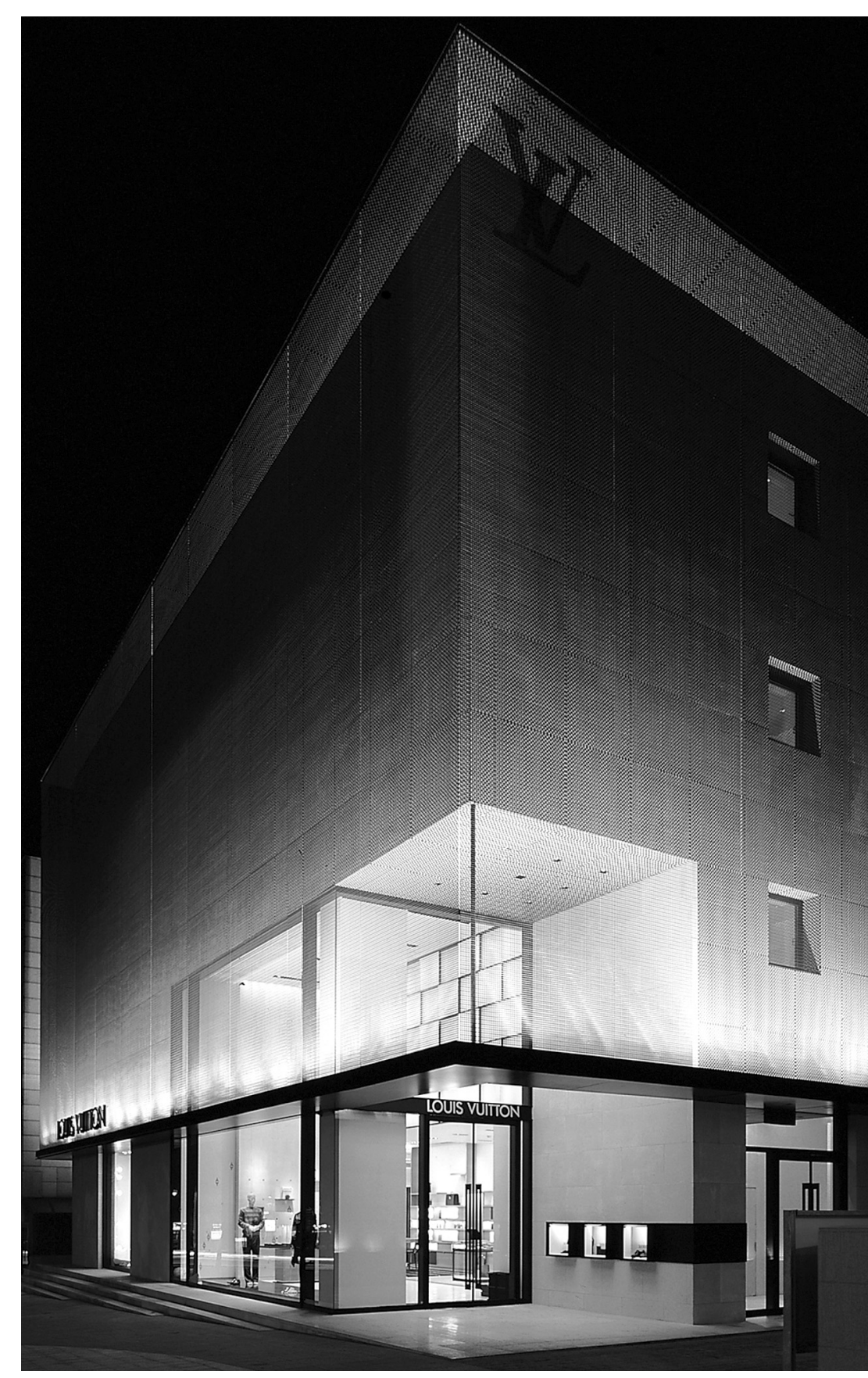

Figure 1 


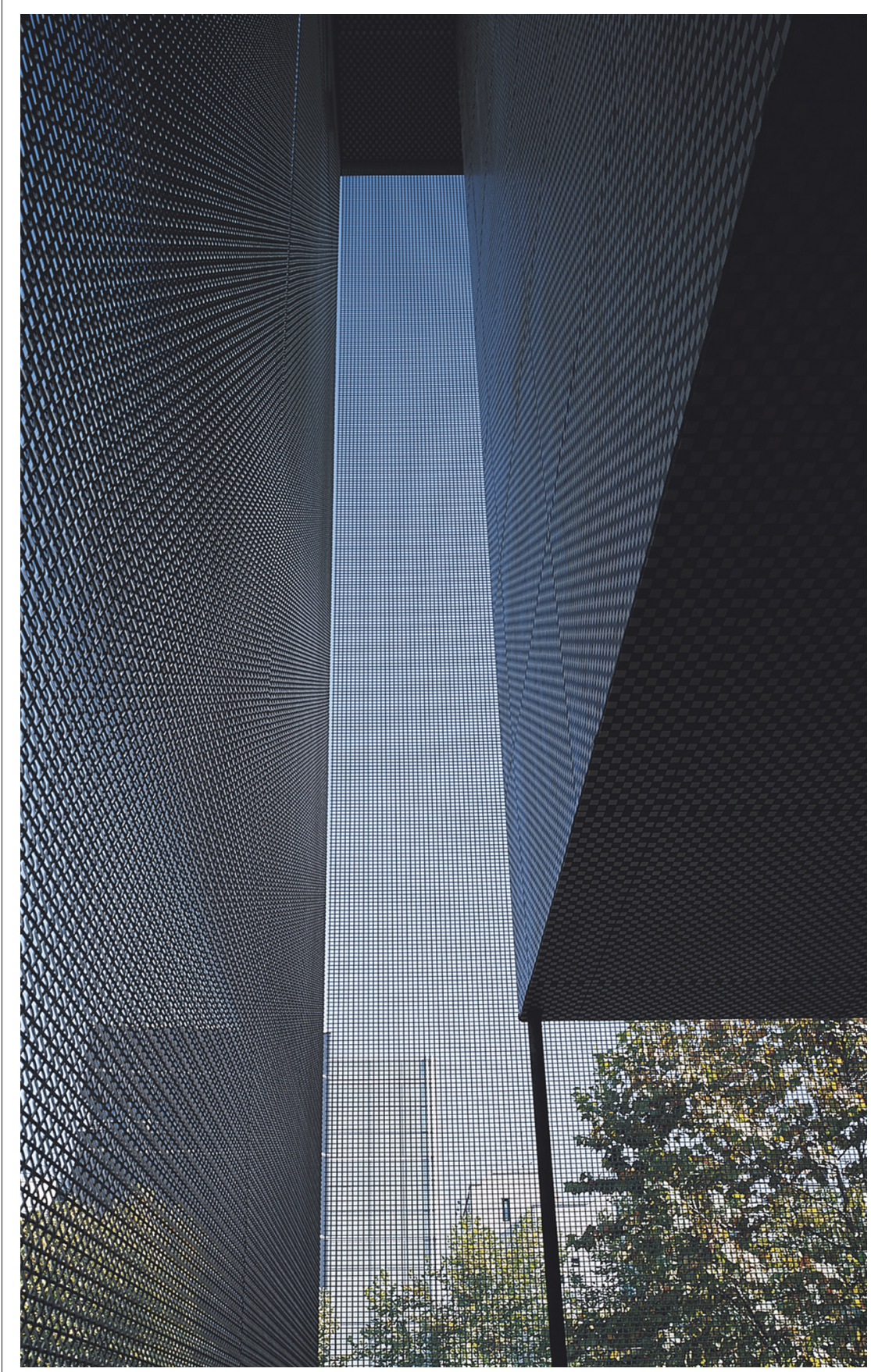

Figure 2 furniture, uncompromising quality of details and finishes, and the complex approvals procedures of building departments and especially clients.

Our initial confrontation with the impact of this extraordinary velocity upon the design process came from our first free-standing building for Louis Vuitton along Chung Dam-Dong street in Seoul, South Korea. Conceived and built in twelve months, the mosaic tiled building shell is loosely shrouded in an veil of stainless steel meshes, optically interacting to generate a shimmering moiré effect. (Figure 1) Creating the double skin with an opaque inner core allowed us to isolate the interior from the exterior to focus independently on the conception of the internal spaces and refinements of the exterior, each with their own specific construction and political agendas. (Figure 2)

\section{Time... and Time Again}

This "divide and conquer" strategy obliged us to learned to juggle not only factors within one project, but also between projects, increasing exponentially the number of issues in the air. At any one time two, three or four projects would be under development simultaneously. The typical methodology of; one project, one team, one entity and one result with a clearlydefined beginning and end, began to mutate into a larger evolving mass of projects developing organically. A continuum of overlapping projects and ideas created an active testing ground where examining successes and failures provided a seemingly end- less acquisition of knowledge. This unique relationship with time created a design process that didn't finish at the beginning of construction, or even at the end of construction.

During the construction of the Seoul building, we also began designing the Sapporo and Tokyo Omotesando projects. The partial transparency of the Seoul façade confirmed the potency of natural light within the retail space. Sapporo, located in the northern region of Japan with it's long winter nights pleaded to make the most of this newfound asset. To achieve this, we distributed windows in a monumental checkerboard pattern, inspired by the Louis Vuitton "damier" motif, along the 150-foot-long, 2-story façade. (Figure 3) The Omotesando building was codesigned with Jun Aoki who generated

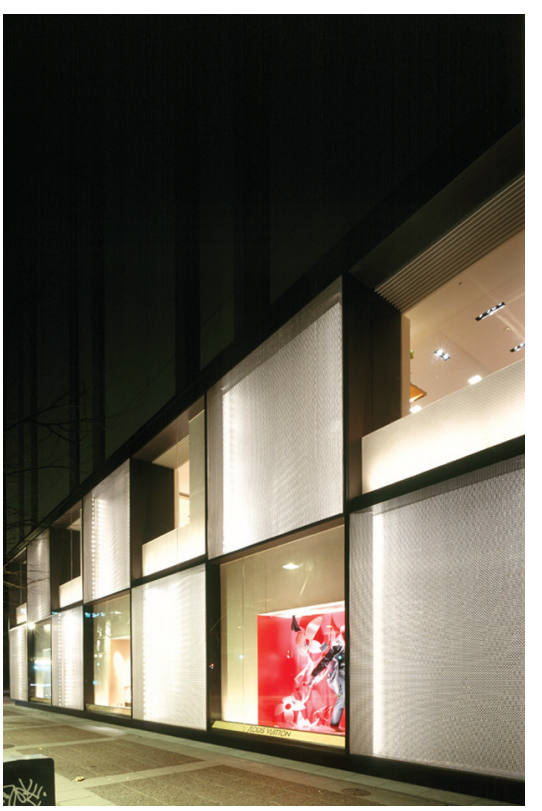

Figure 3 


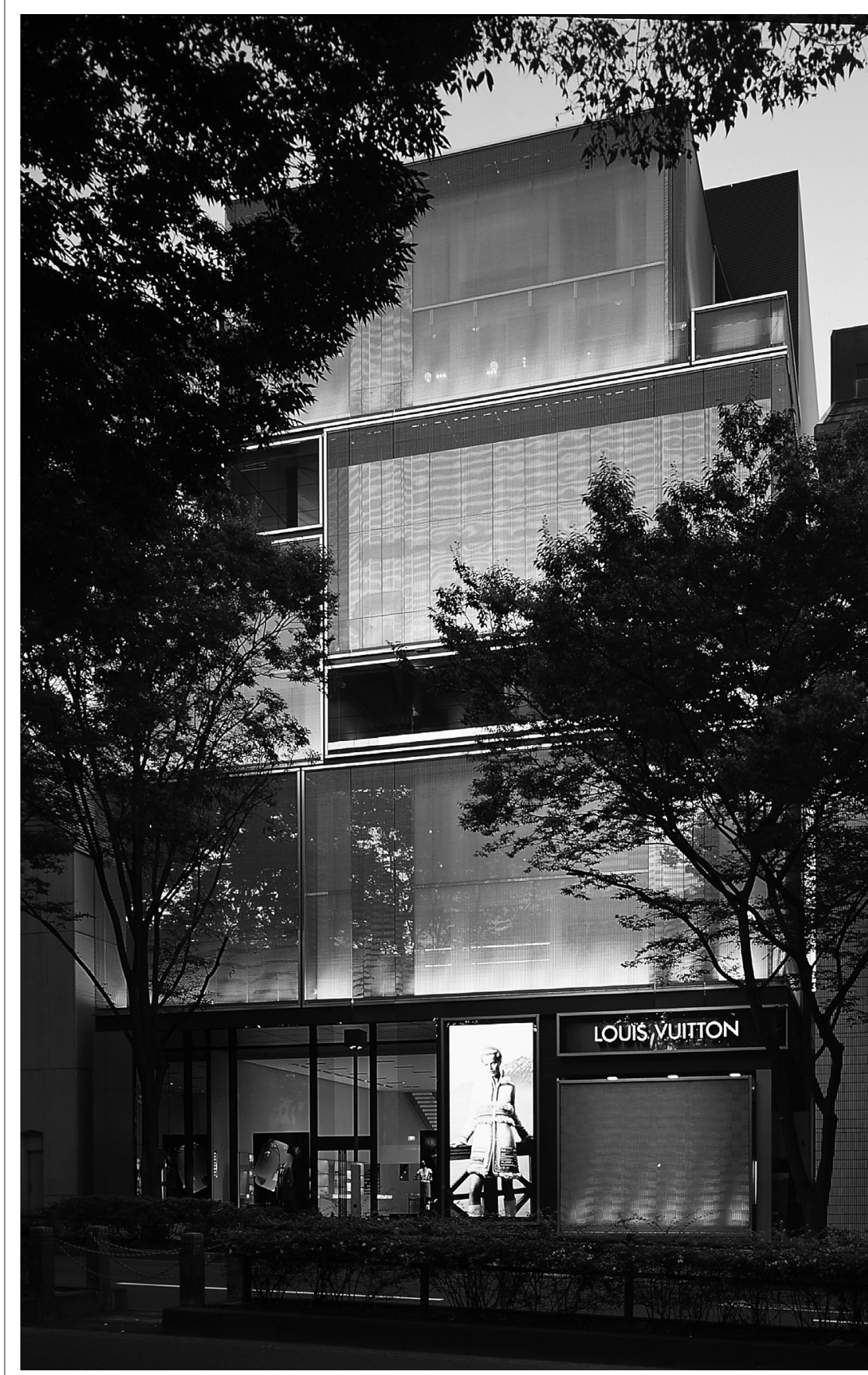

54

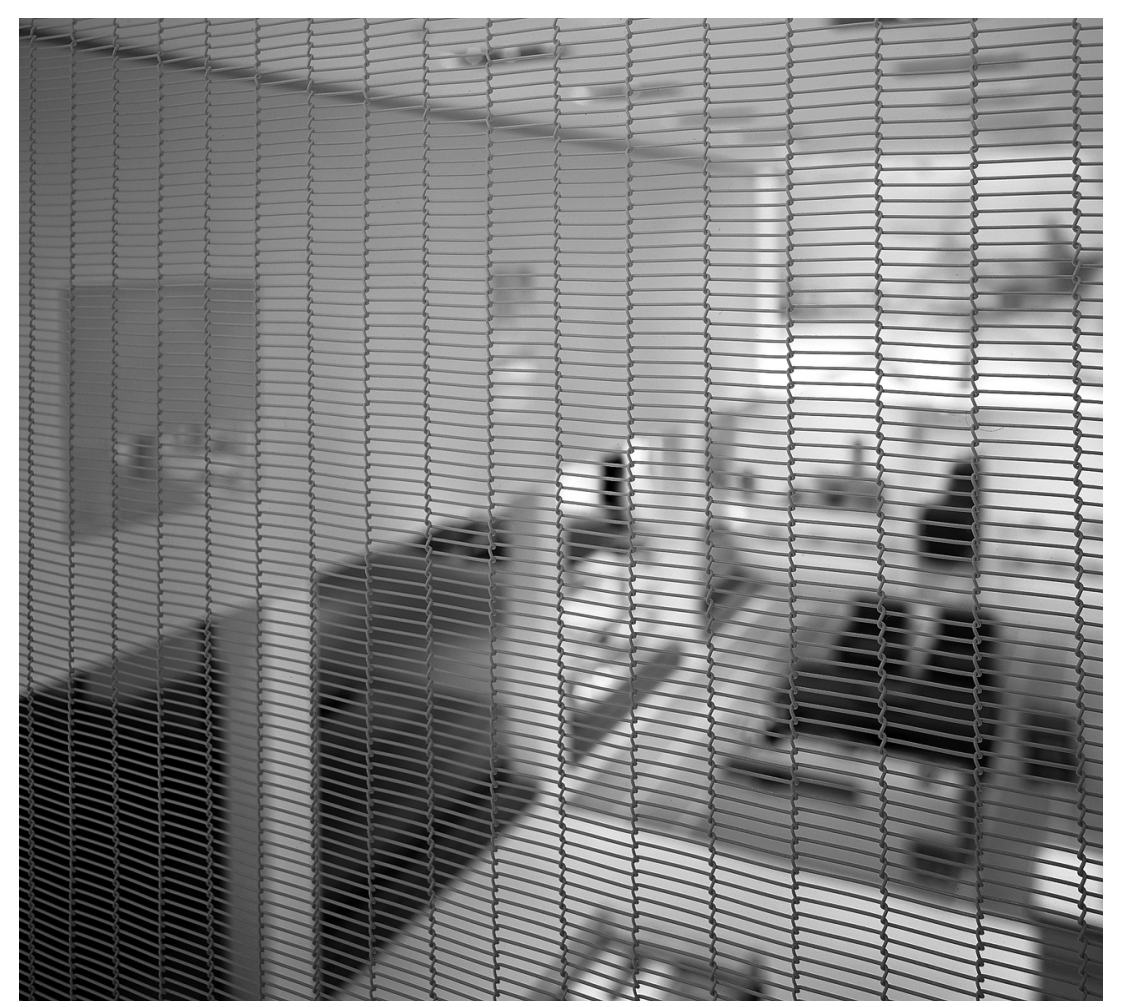

Figure 5

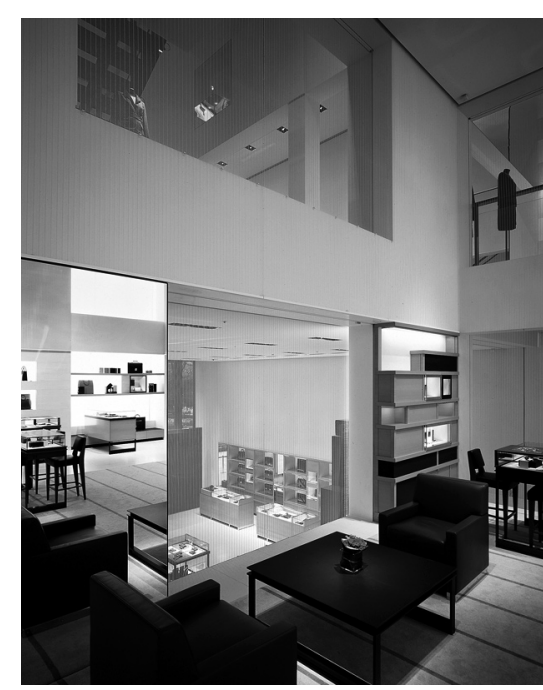

Figure 6

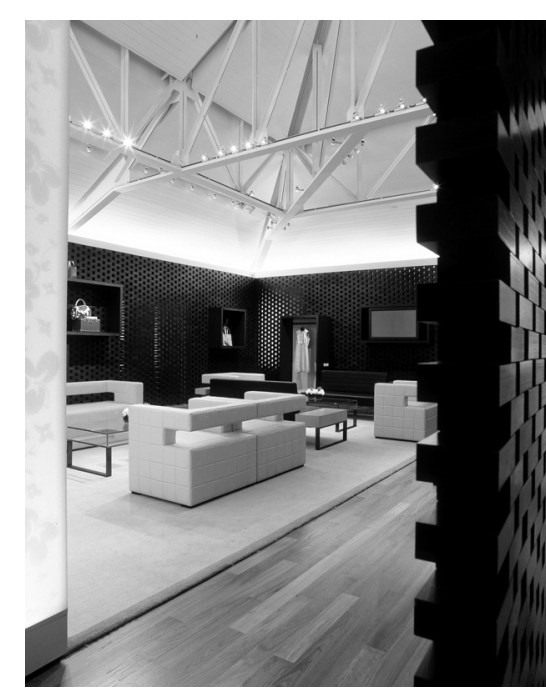

Figure 7 


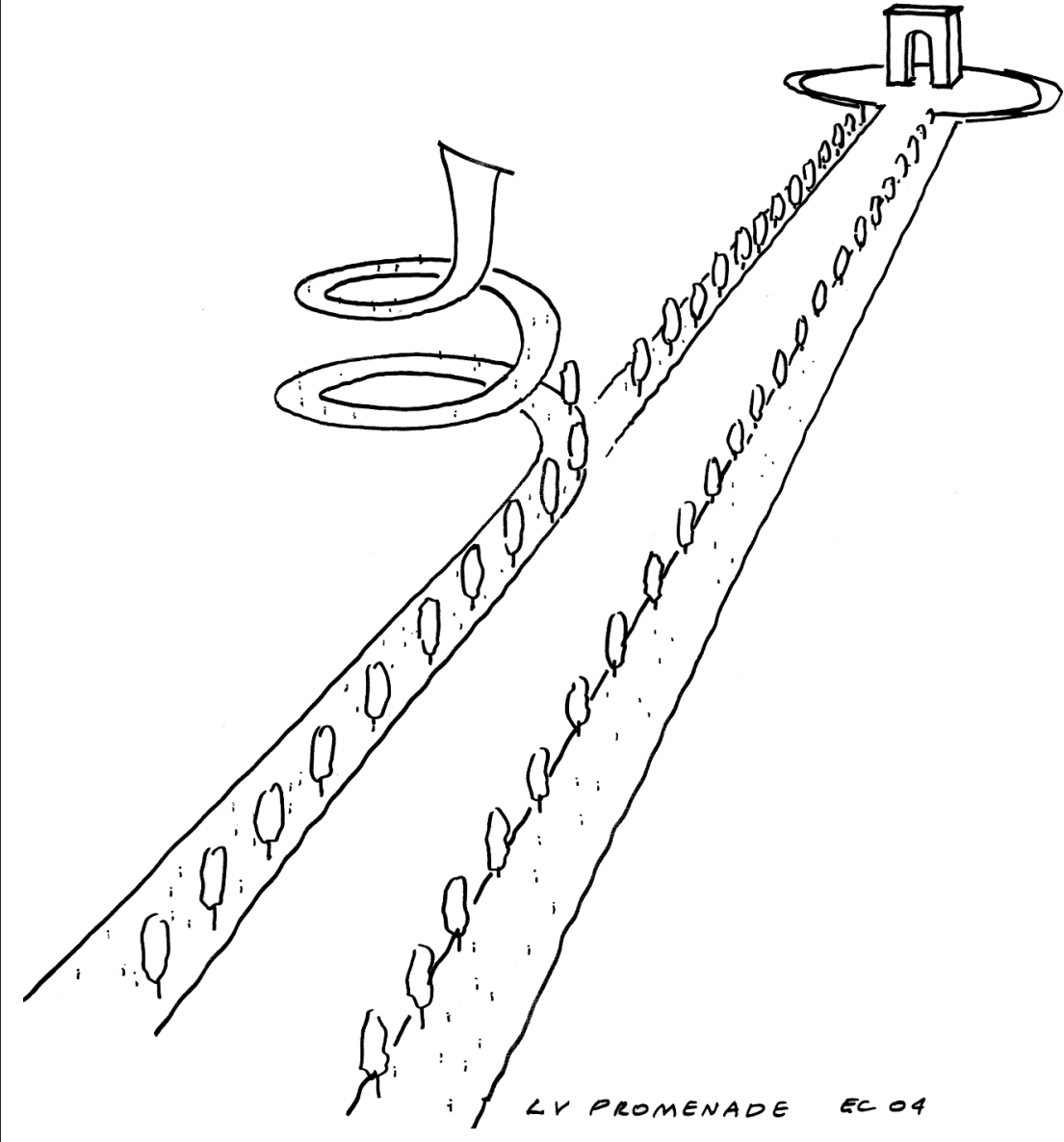

Figure 8

the building envelope by appropriating and advanced the collective architectural language and stacking several Seoul buildings on top of each other to mimic a pile of $\mathrm{LV}$ travel trunks. (Figure 4) We, in turn, extended this metaphor internally by designing the trunks' lining inside the stacked twostory volumes by utilizing a fine metal mesh developed industrially for straining chocolate almonds. (Figures 5 and 6) These linings served to ambiguously delineate the spaces and simultaneously act as guardrails for the corresponding floors above. From a macro perspective this also represents the beginnings of the development of an internal façade concept that subsequently evolved in the Waikiki project as a ribbon wall of stacked wenge wood bricks demarcating a private VIP area within the public retail space. (Figure 7) At a larger scale, the interior in the Paris Champ Elysees building as a multi-level, spiraling skin. Made of 110,000 cast aluminum diamonds electroplated in silver and gold, the serpentine interior facade filter punctually inlayed with crystal, wood, and leather wraps the street front promenade inwardly to become the datum for the largest luxury brands store to date. (Figure 8, 9, and 10) And finally, facade advances to its culmination

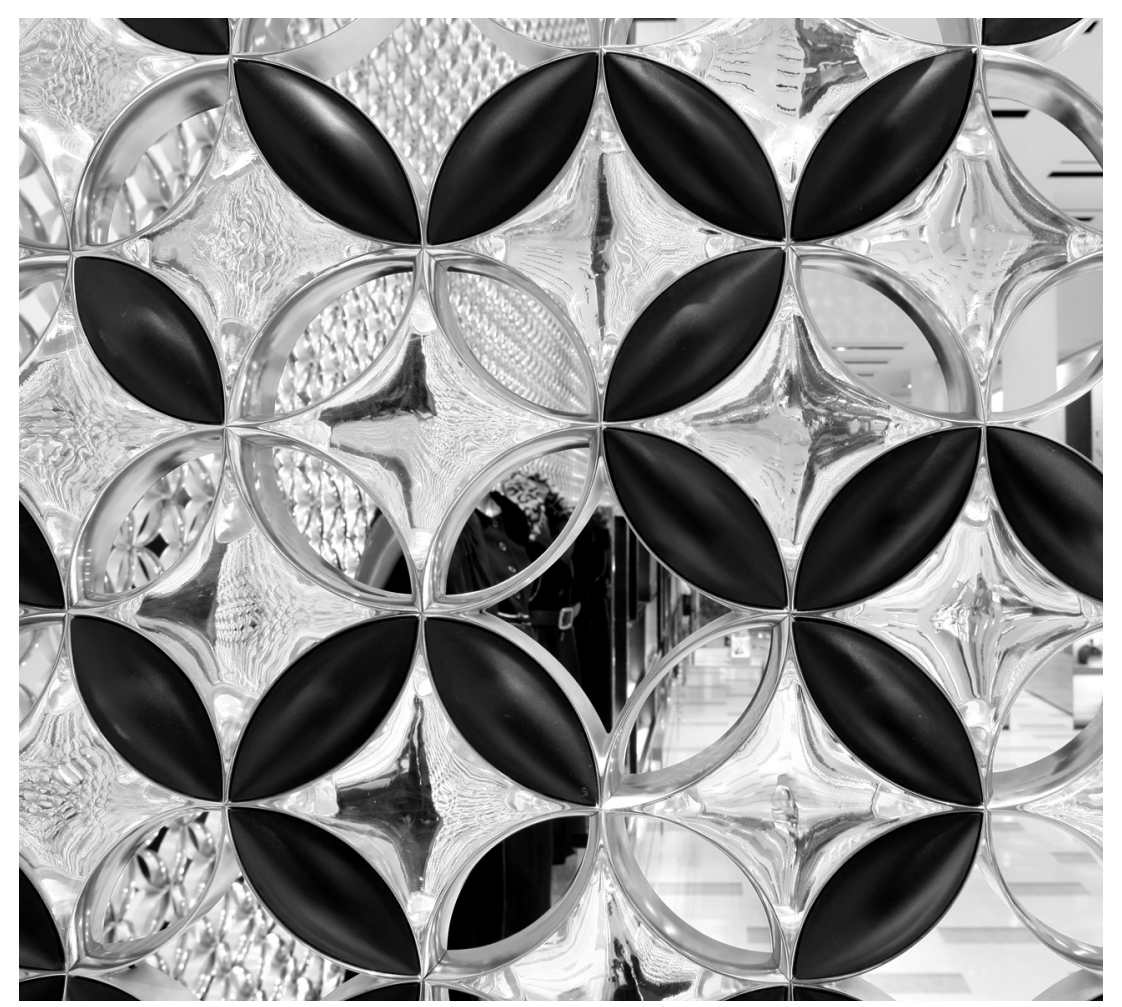

Figure 9

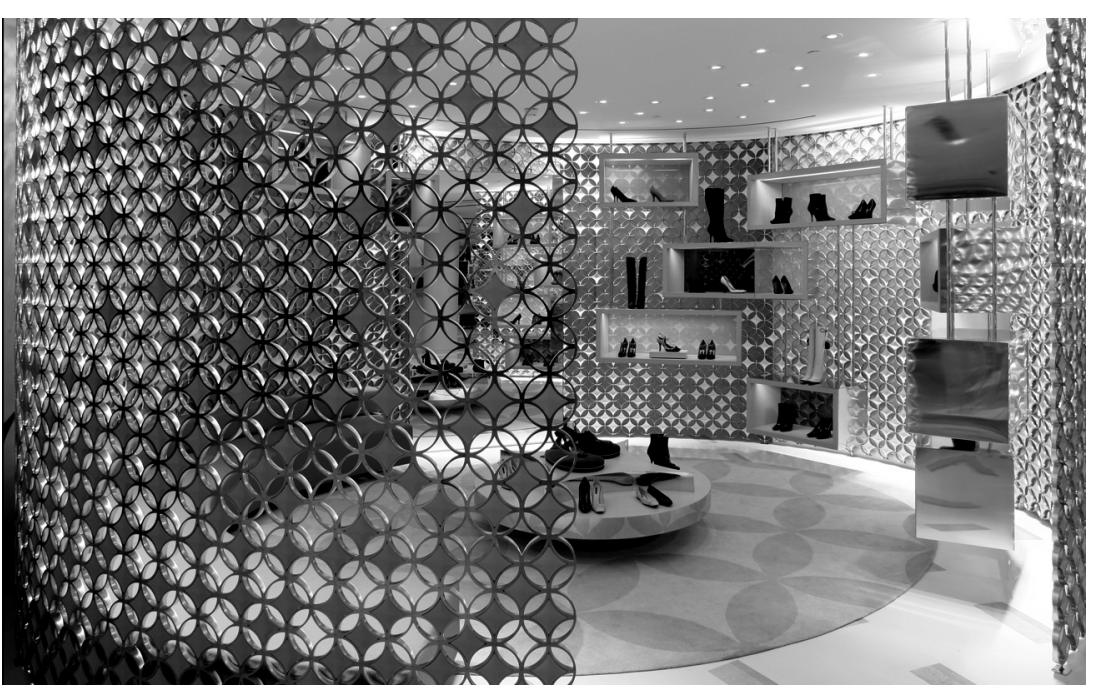

Figure 10 


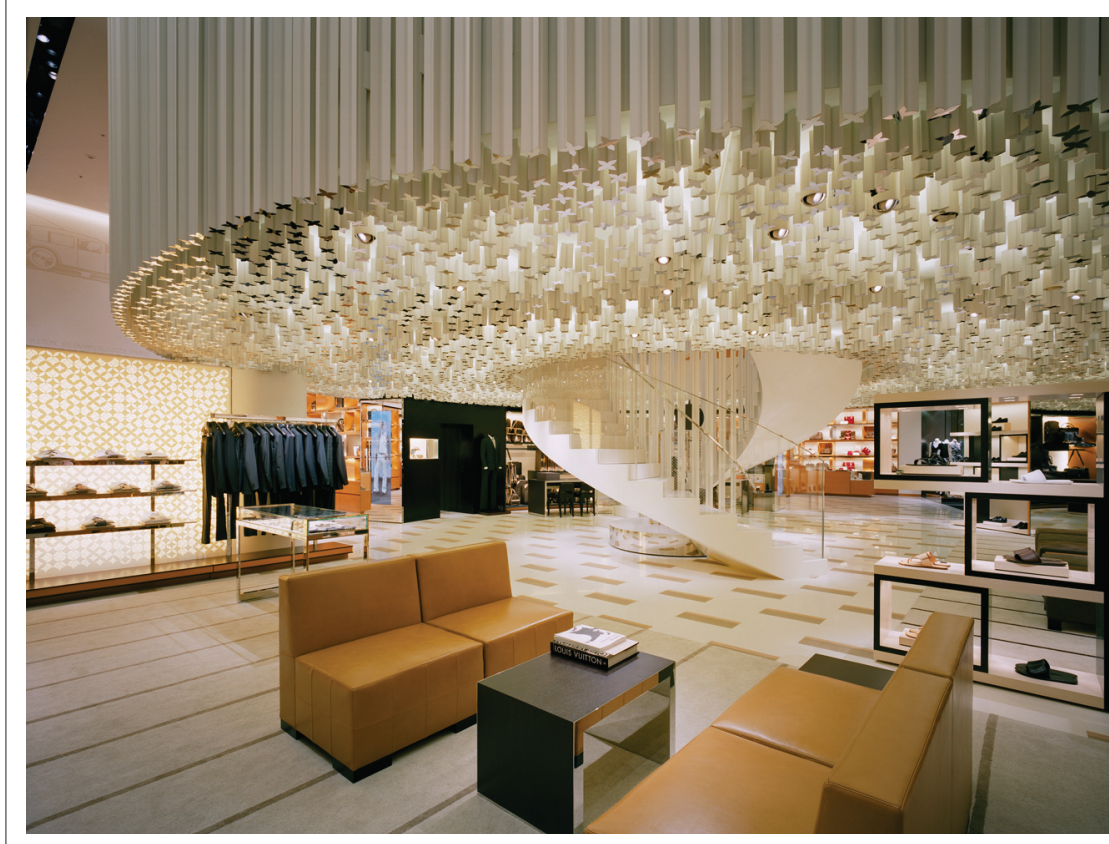

Figure 11

the internal façade metamorphoses into a "building-within-a-building" in our recently-completed Nagoya project where 60,000 extruded aluminum LV monogram flowers capped in polished stainless steel and brass are grouped to make up the floating mezzanine and support the suspended double helix stairs. (Figures 11, 12, and 13) The Nagoya mezzanine appears as a formal inversion to its predecessor, the six-story atrium/dome shaped by 2,000 stainless steel rods in the Paris building. (Figure 14) These examples are only threads of what is a complex weave of an organically evolving context.

\section{Form Follows Fashion}

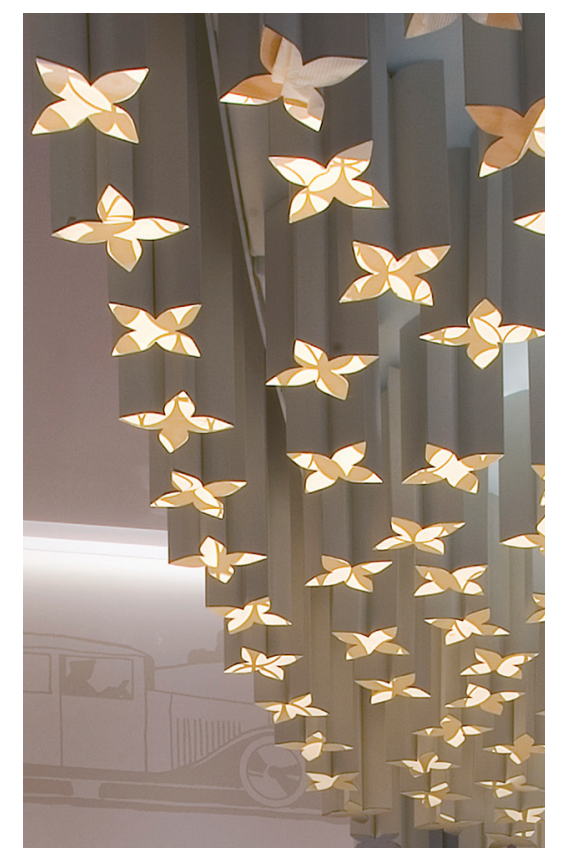

Figure 12

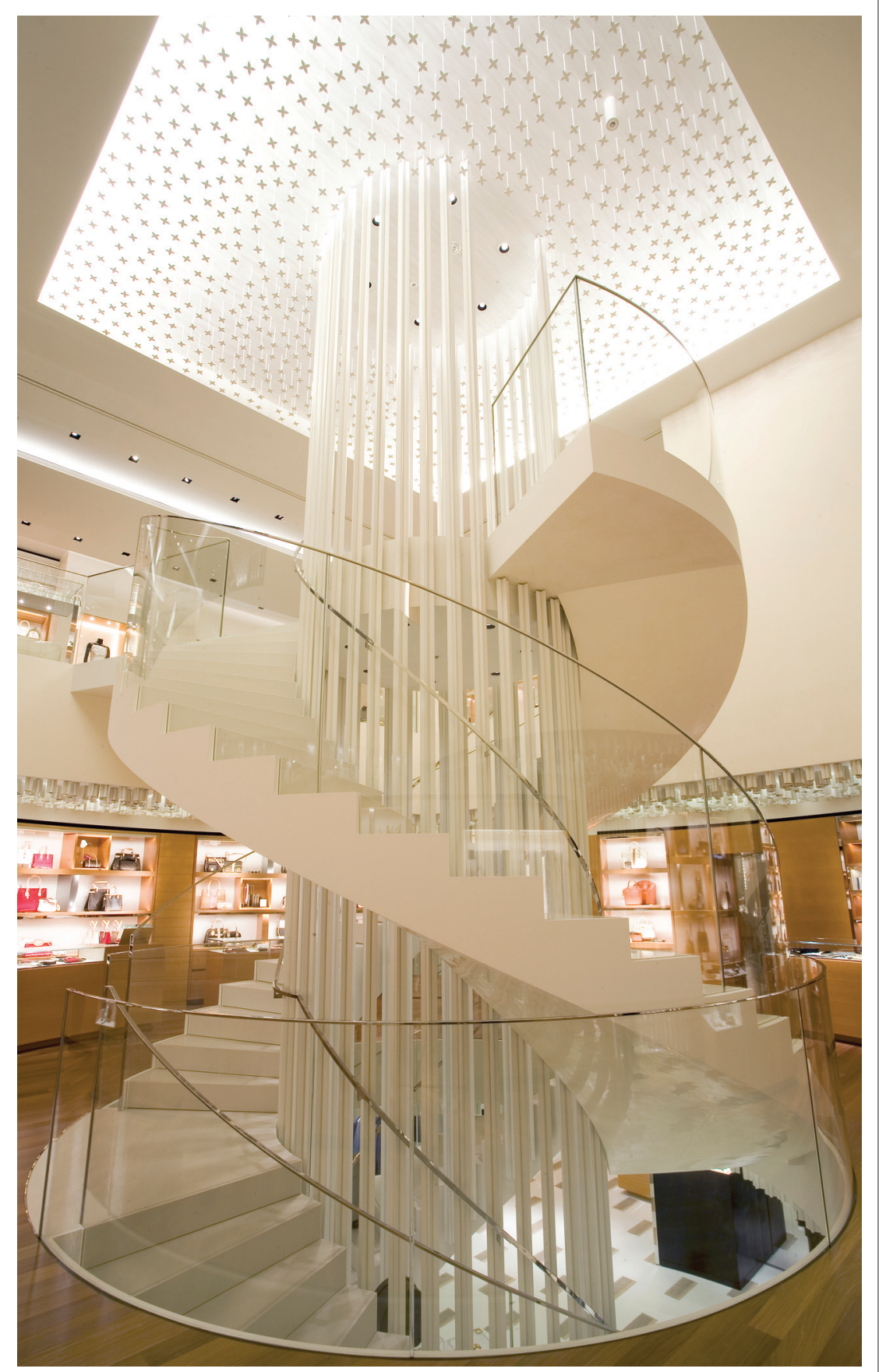

Figure 13 


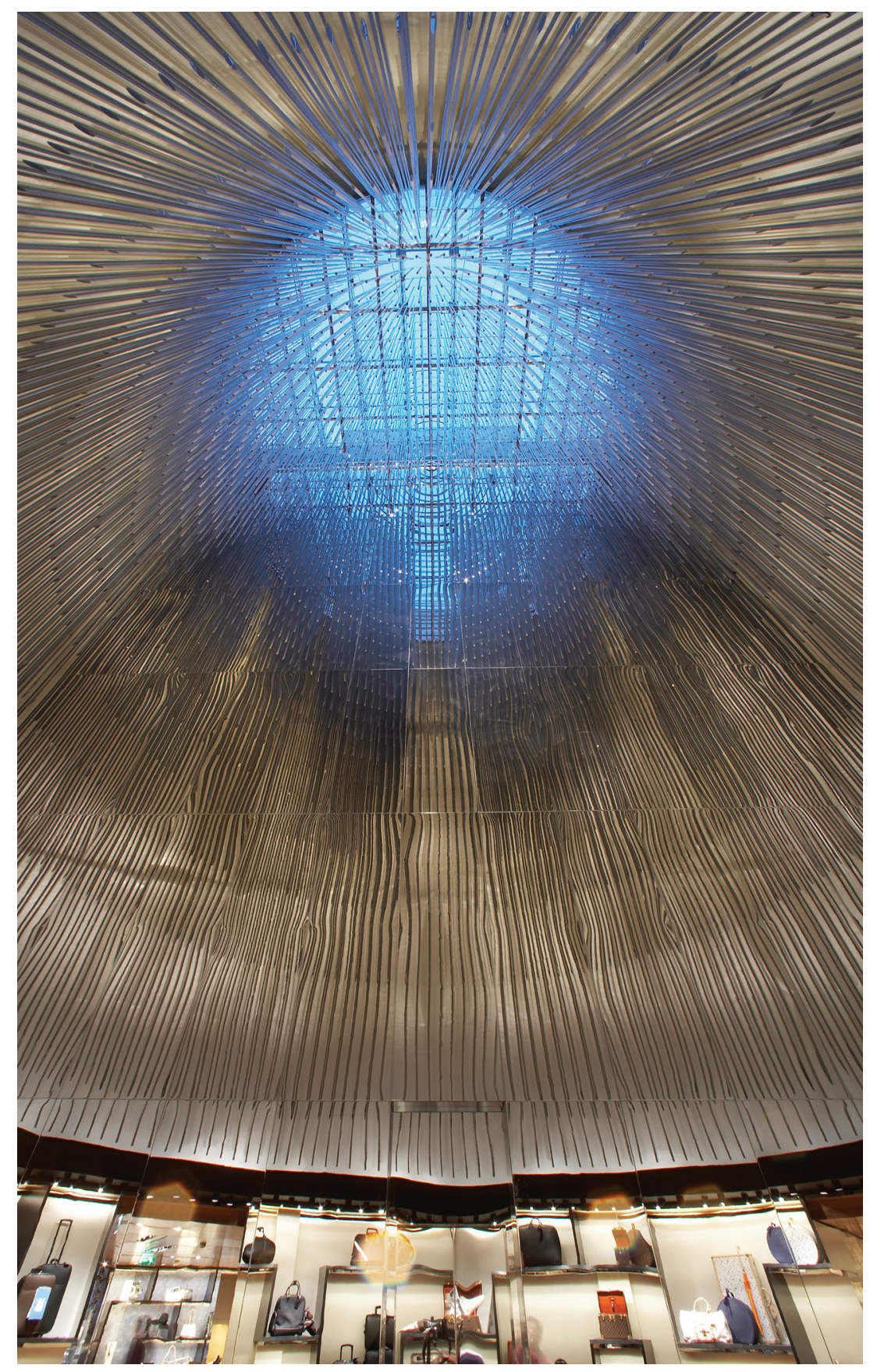

Figure 14

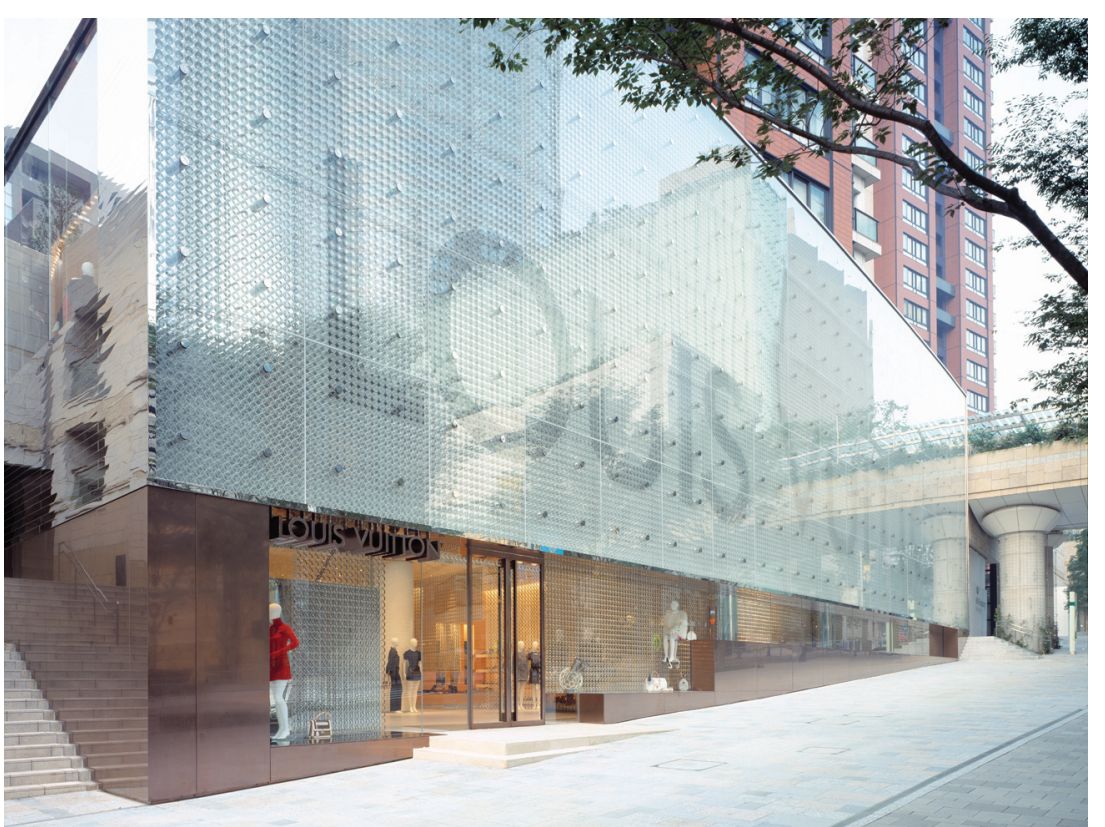

Figure 15

1990 before requiring renovation was approximately ten years, in 1997 it was seven years, in 2002 it was around five years and today...it's all the time. For fashion brands the concept of seasonal change for product collections is standard practice. Yet strangely for store architecture, despite the evolving nature of the program, change was met with resistance for everything except the areas dedicated to window displays. In divergence, our conception for the LV Roppongi Hills building was based on embracing change annually, seasonally, monthly and even daily. The honeycombed glass tube façade was envisaged as an enormous microscope slide encouraging views to the changing activity within. (Figure 15) An ephemeral curtain of overlapping stainless steel tubes, is devised as an architectural element easily manipulated to reshape the ever changing product zones. The residual central area acts as an urban plazacum-window display where visitors nequins in a continuously altering the choreography. (Figure 16) A "bags bar" displaying leather goods was devised with cubic wall extrusions that can shift horizontally in or out to adapt to the latest merchandising scenarios. (Figure 17) An expanded variation of vertically disposed cubic stalactites and stalagmites was explored in our Ginza project, designed last year. (Figure 18) The introduction of easily reprogrammable moving images are integrated into the architecture by imbedding optic fibers within the stone floor and stairs treads in Ropintermingle with upwards of 70 man- 


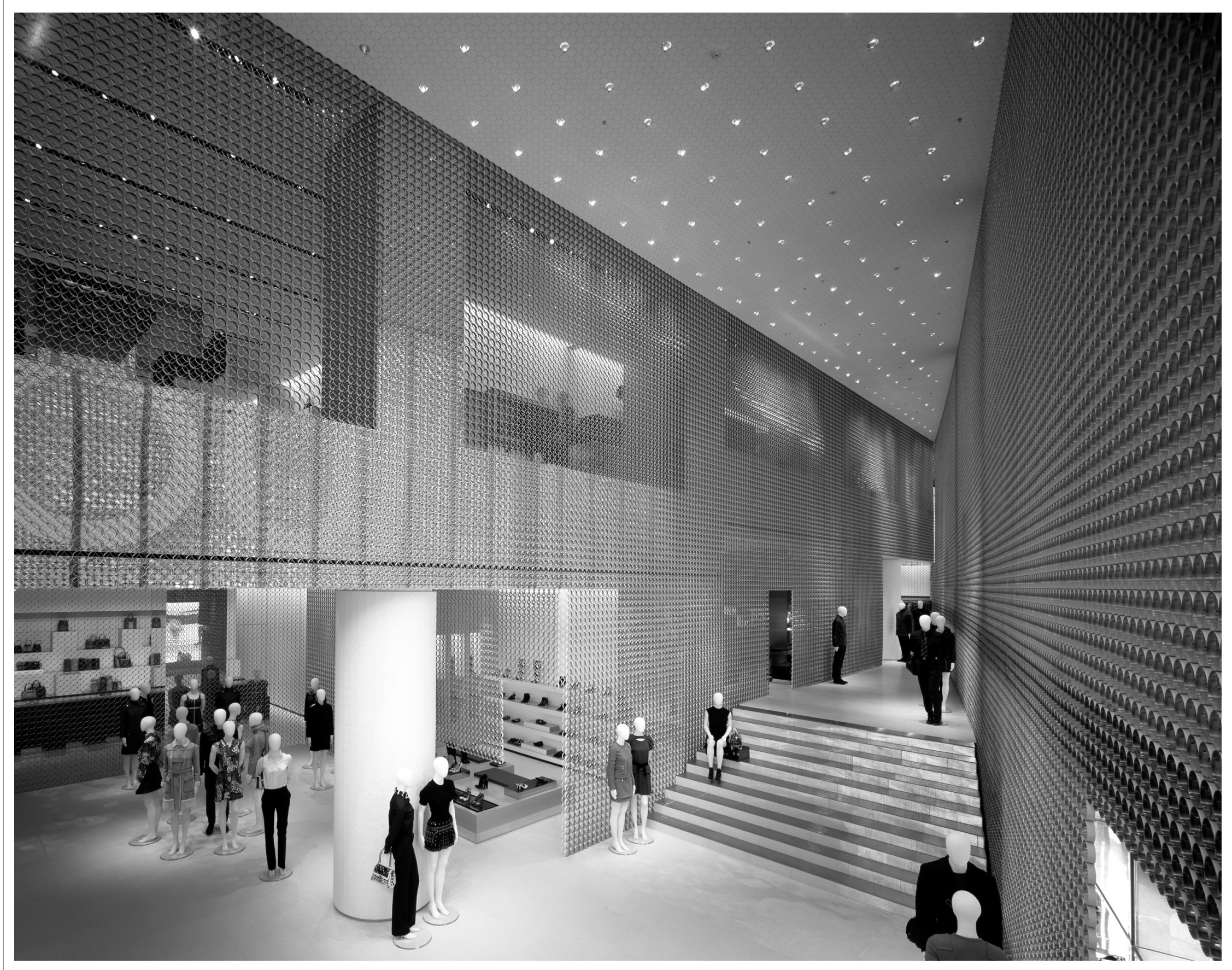




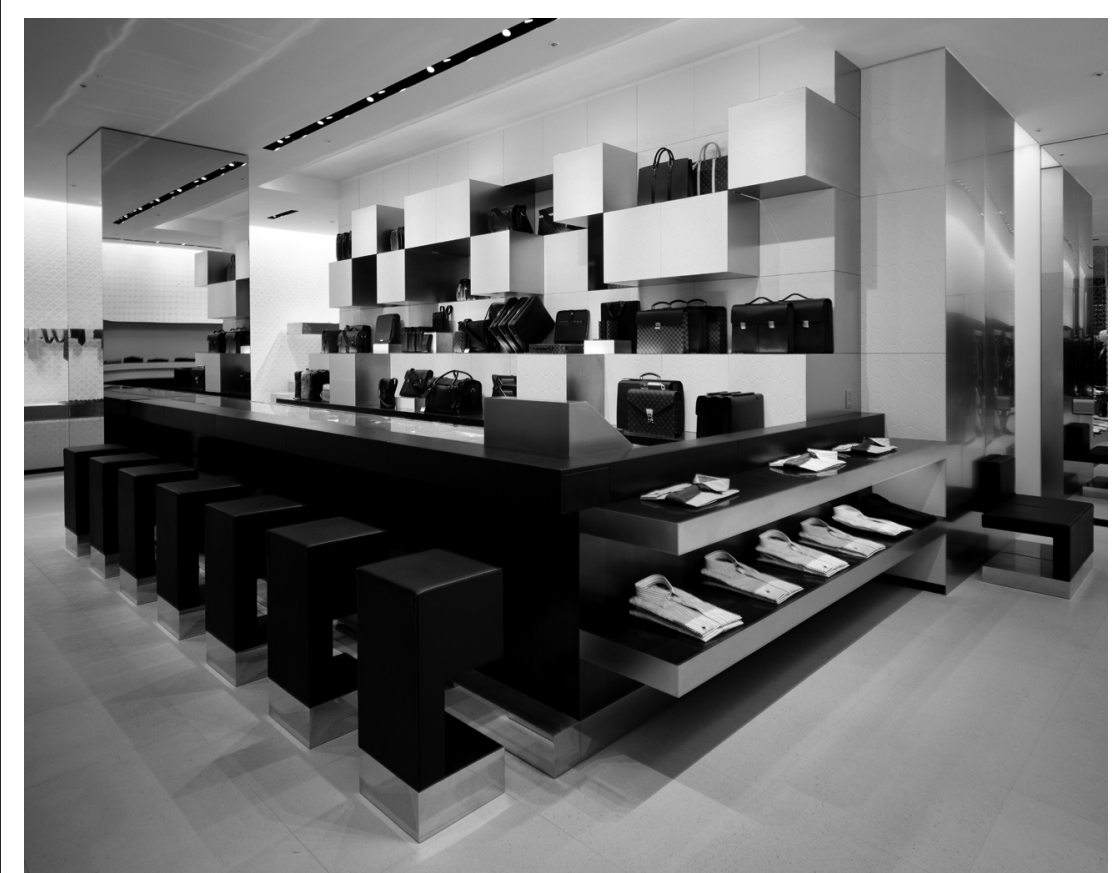

Figure 17

pongi and in a colossal escalator wall in Paris. (Figures19 and 20) Even the ceiling lighting fixtures are easily adjustable with a hand held remote control through the inventive integration of infrared receptors and motors. For the first time, fashion and architecture are synchronized in time.

Branded retail design provides ideal examples to demonstrate temporalities touch upon architecture, however it is far from limited to only this functional type. The main town plaza design for Ecija, Spain is a project whose principal ideas are generated in response to a context of projected changes in time. Our design is composed of two transforming horizontal planes. The first is a suspended undulating blanket

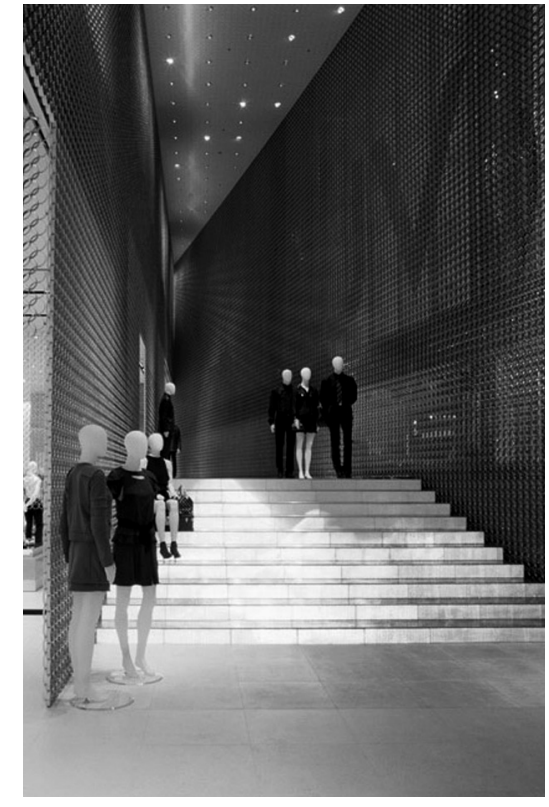

Figure 19

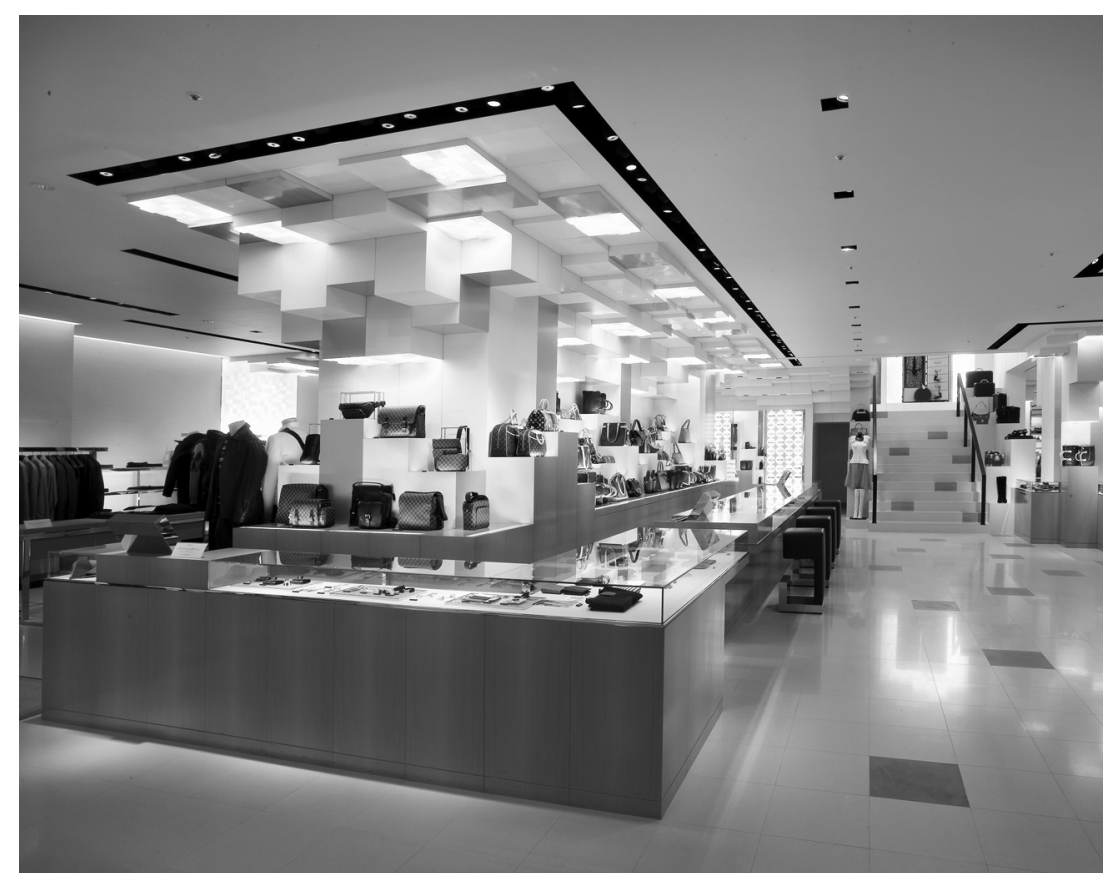

Figure 18

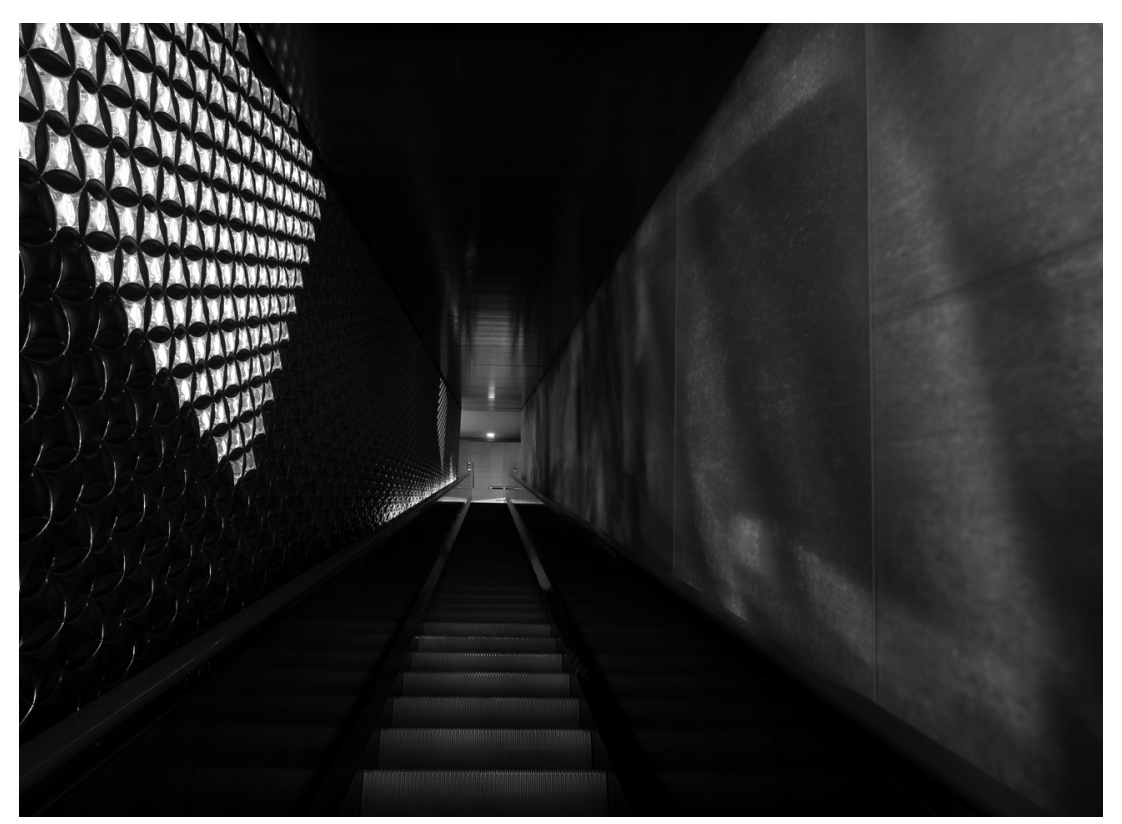

Figure 20 


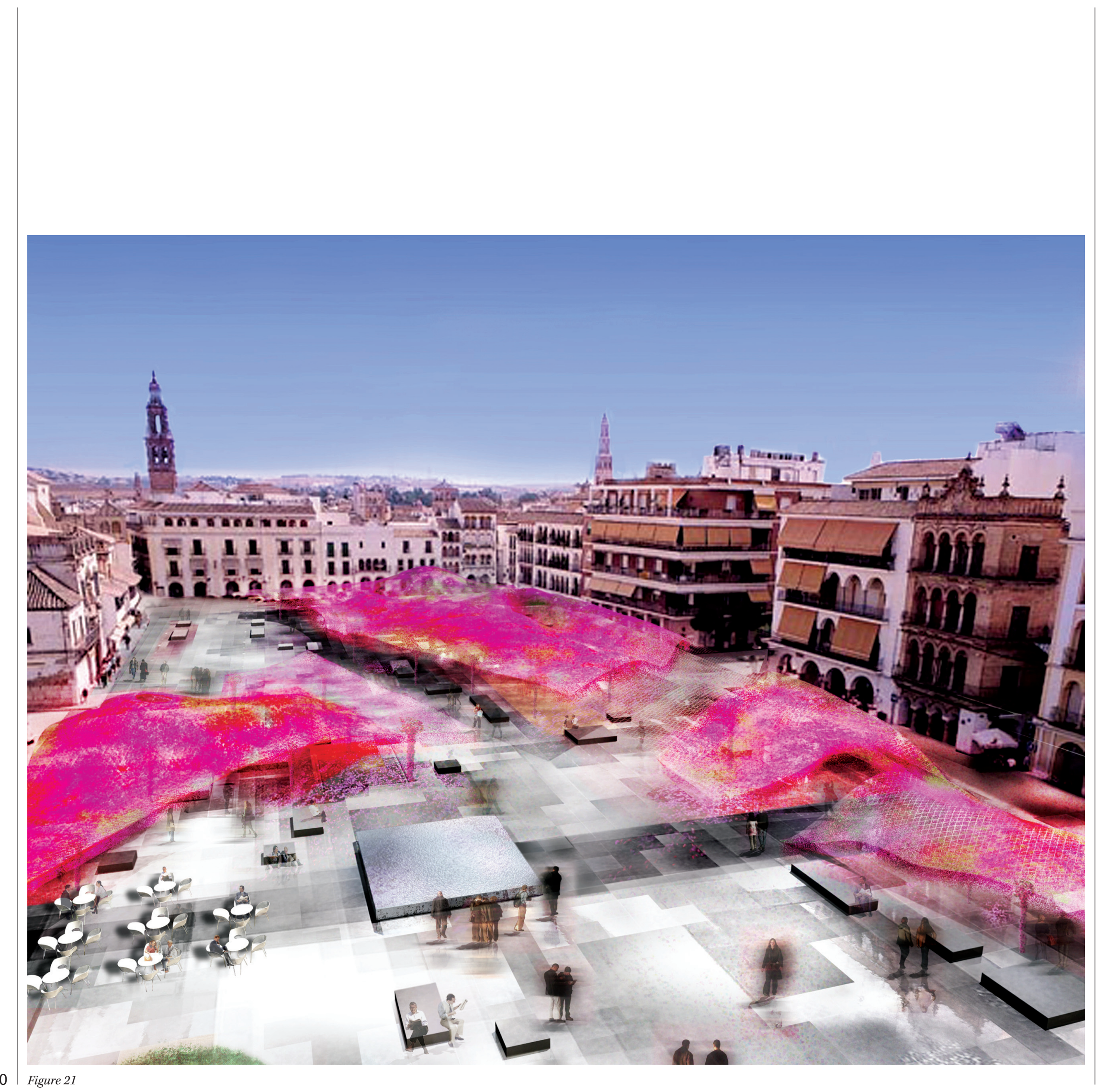




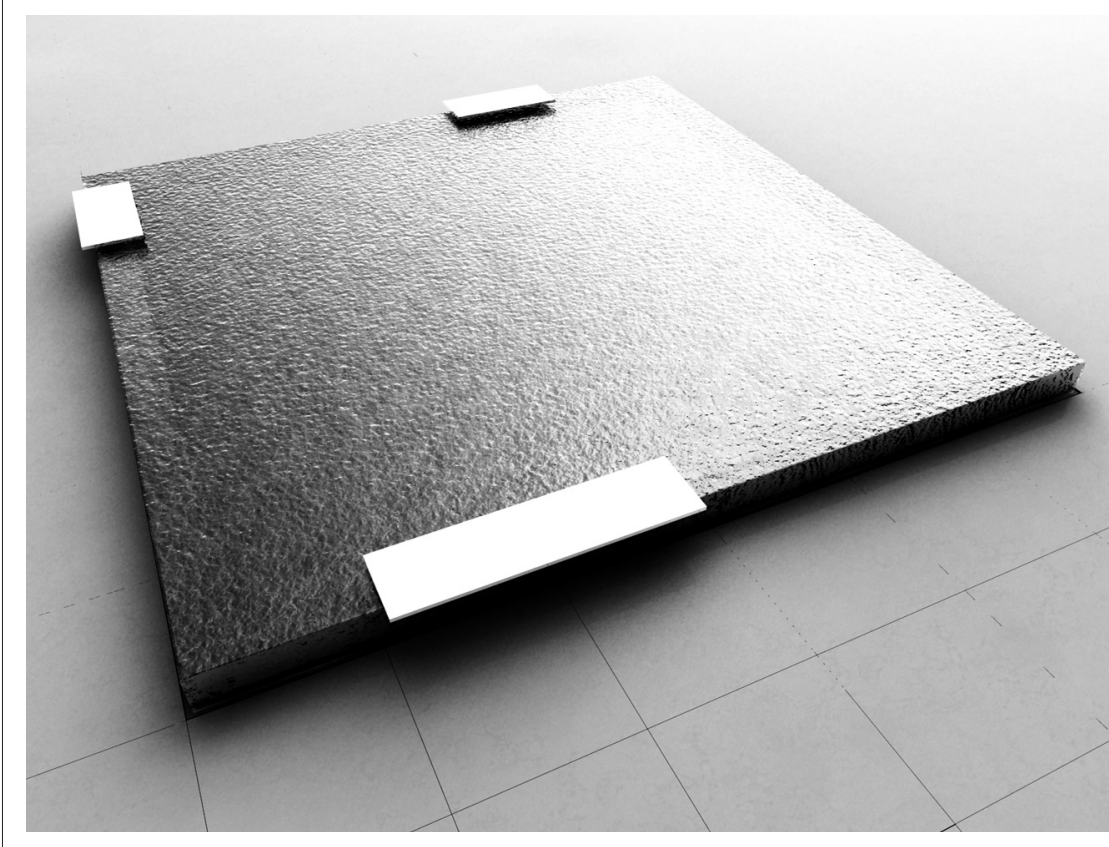

Figure 22

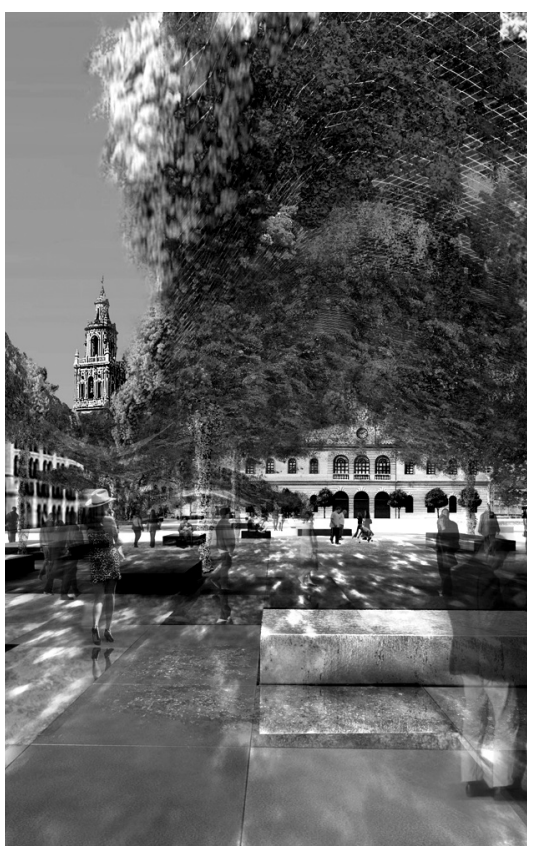

Figure 23

Figure 24 of indigenous bourgonvillia growing on Teflon tension cables shaped by a variety of public activities (sitting, protests, markets, playing, social and religious promenades, etc). The second, the plaza itself, is paved in a pixelized grid of marble rising up from the ground plain to form benches, fountains, market tables, and bollards. (Figures 21, 22, and 23) Both horizontal systems have integrated adaptability into their conceptual infrastructures in preparation for change.

Finally, to finish with a future project that has yet to be realized, but already exemplifies the influence of temporality upon architecture. The Fortress of Polignac, perched for over 900 years on a volcanic outcropping in the center

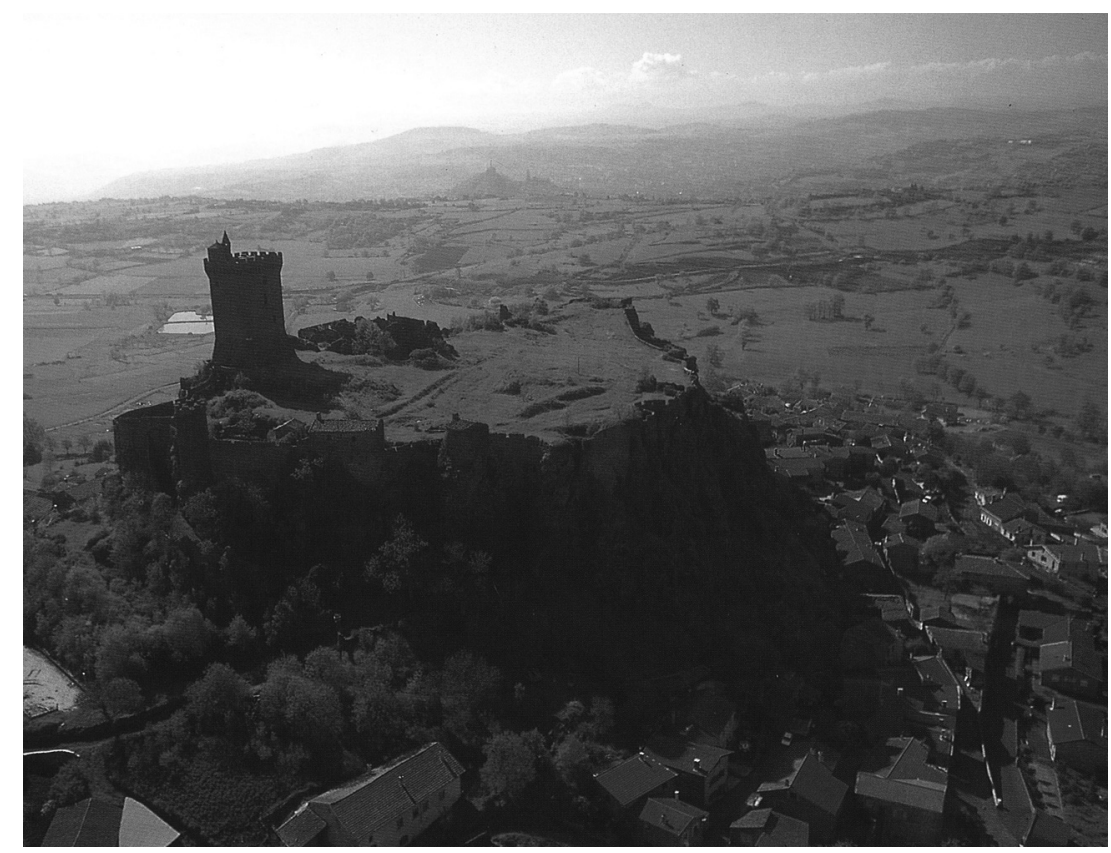

of France, has been built, rebuilt, and extended through numerous generations of the Polignac family. (Figure 24) Today, the Princess Constance of Polignac would like to continue this architectural tradition of innovative improvement of her property, but is greatly hampered by historic conservation regulations that inhibit change. Ironically, the way forward will come about through the creation of "temporary" architecture interventions that can appear and disappear in a matter of days as opposed to hundreds of years.

These examples are just glimpses of a series of temporal moments in our work. They are not meant to outline a specific way forward for the making of architecture for the future, but they are meant consider a different idea of what architecture means by digging up some traditional timeless and eternal foundations and re-examining them in the present.

\section{Photo Credits}

Figures 1, 2: Nakamoto

Figure 3: H Ueda

Figures 4, 5, 6, 11, 15, 16, 17: D Ano Figures 7, 8: E Carlson

Figures 9, 10: S Muratet

Figures 12, 13, 14, 18, 19, 20: J Cohrssen

Figures 21,22,23: CARBONDALE

Figure 24: E Rioufol, O Brunet 